\title{
Climate Change and Snow Tourism in Australia
}

\section{Urs König, Sydney}

\section{Introduction}

The theory that greenhouse gas increases could cause global warming has been recognised in the scientific world for about a century. It was, however, only in the 1980 s that the scientific debate over future climate change due to an enhanced greenhouse effect became intensive. Since the mid 1980s there has been an escalation in publications on climate change and considerable progress has been achieved in our understanding of impacts from an increasing greenhouse gas concentration on global climate. Despite many remaining uncertainties, the most recent research on climate change due to an enhanced greenhouse effect undertaken by the Intergovernmental Panel of Climate Change (IPCC) tends to support the theory that the Earth's climate is changing and that: «the balance of evidence suggests that there is a discernible human influence on global climate» (Houghton et al. 1996: 39).

Future climate change as projected by the IPCC may affect tourism in several ways. First, it is expected that such climate change would have significant implications for tourist activities. Under the effects of climate change, certain tourist activities (e.g., snow-related or beach tourist activities) may only be possible in certain reduced areas or may even disappear. Generally, tourist activities which require major investment in fixed facilities and cannot be diversified elsewhere (e.g., downhill skiing) would be most negatively affected by climate change. On the other hand, it is possible that certain tourist activities (e.g., golf or camping) may be positively affected. Additionally, climate change would have impacts on the natural and built environment and therefore may change the attractiveness of the landscape (PRICE 1994). This expectation is important because much tourism is based on an attractive landscape (Cohen 1978, Pigram 1980).

Considering the importance of climate change to the tourism industry, there is a paucity of research on impacts of climate change on tourism. For instance, SMITH (1990) and ABEGG (1996) argue that tourism has been largely neglected by the climate impact researchers. Moreover, WALL (1992: 215) pointed out clearly that: «... Although the implications [of climate change] for tourism are likely to be profound, very few tourism researchers have begun to formulate relevant questions, let alone to develop methodologies which will further our understanding of the nature and magnitude of the challenges which lie ahead.»
The lack of climate change impact research on socioeconomic systems in general and the tourism industry in particular may be explained by the complexity and unpredictable nature of these systems. Unlike in the field of climate change impact research on biophysical systems, where many non-climate factors can be held constant in order to single out the impacts of climate change, the nature of socioeconomic systems precludes such analysis (see TimmERmanN 1989). In the case of tourism, changing non-climatic factors such as leisure trends, tourism policies or the world economy make projections of the impacts of climate change on the industry very difficult.

Most of the climate change impact research on tourism to date has investigated impacts on the ski industry (e.g. LAMOTHE \& PérIaRd CoNSUltants 1987; ÖsterReICHISCHE AKademie DER WissensChaften 1993, WaLl 1993, ABEGG 1996). Fewer studies have investigated such impacts on coastal tourism (e.g. KRUPP 1995, United Kingdom Climate Change Impact Review Group 1996), freshwater tourism (e.g. Keys et al. 1990), camping and golf (e.g. WALL et al. 1985).

Studies on the impacts of climate change due to an enhanced greenhouse effect on the snow-pack in Australia suggest that climate change would increase the frequency of winters with little natural snow (HAYLOCK et al. 1994, WhetTon et al. 1996). Under this climate change, the alpine tourism industry would have to deal more often with shortened and more marginal ski seasons. This is expected to reduce the number of skier days in resorts, despite extensive snow-making, resulting in similar negative impacts on businesses as in the poor snow seasons of 1988 and 1993. Indeed, it has been suggested that because of the already marginal snow conditions under current climate, even a small temperature increase would have serious impacts on the Australian winter tourism industry (GALlOWAY 1988).

- First, this paper provides a brief introduction to the Australian winter tourism industry.

- Second, the paper shows how climate change due to enhanced greenhouse effect may influence the snowreliability of Australian ski fields.

- Third, the perception of representatives of the Australian winter tourism industry concerning the possibility of changing climate is discusssed and possible response strategies of the ski industry to climate change are examined. 


\section{The Australian winter tourism industry}

Winter tourism, together with water resource operations, are the largest activities in the Australian Alps. Currently, there are ten ski resorts in Australia. They are either grouped together in the South-East of New South Wales just to the east of the Great Divide) or more scattered over the alps of Victoria (see Figure 1).

Most ski resorts are located in or at the border of a national park (Kosciusko National Park, New South Wales; Alpine National Park, Victoria). Compared with European standards, the ski fields all have modest vertical drops. In terms of both mean elevation and mean annual snowfall, the Australian ski fields are at the low- er end of global norms (Hewirt 1997). Nevertheless, the largest Australian ski resort, Perisher Blue, offers more than 1250ha of downhill ski area and 50 transport facilities (chair lifts, T-bars and rope tows) with a transport capacity of 47000 skiers/hour, which means that it has one of the largest individual resort capacities in the world (HEwITT 1997). The winter tourism industry is the main economic contributor to Australia's alpine areas, and is therefore of significant regional economic importance (BOYLEN 1997). The winter tourism industry contributes approximately A $\$ 410$ million per annum to the Victorian and New South Wales State economies and creates around 12000 seasonal full-time jobs during good snow seasons (BUCKBY et al. 1993, KPMG Management Consulting 1994).

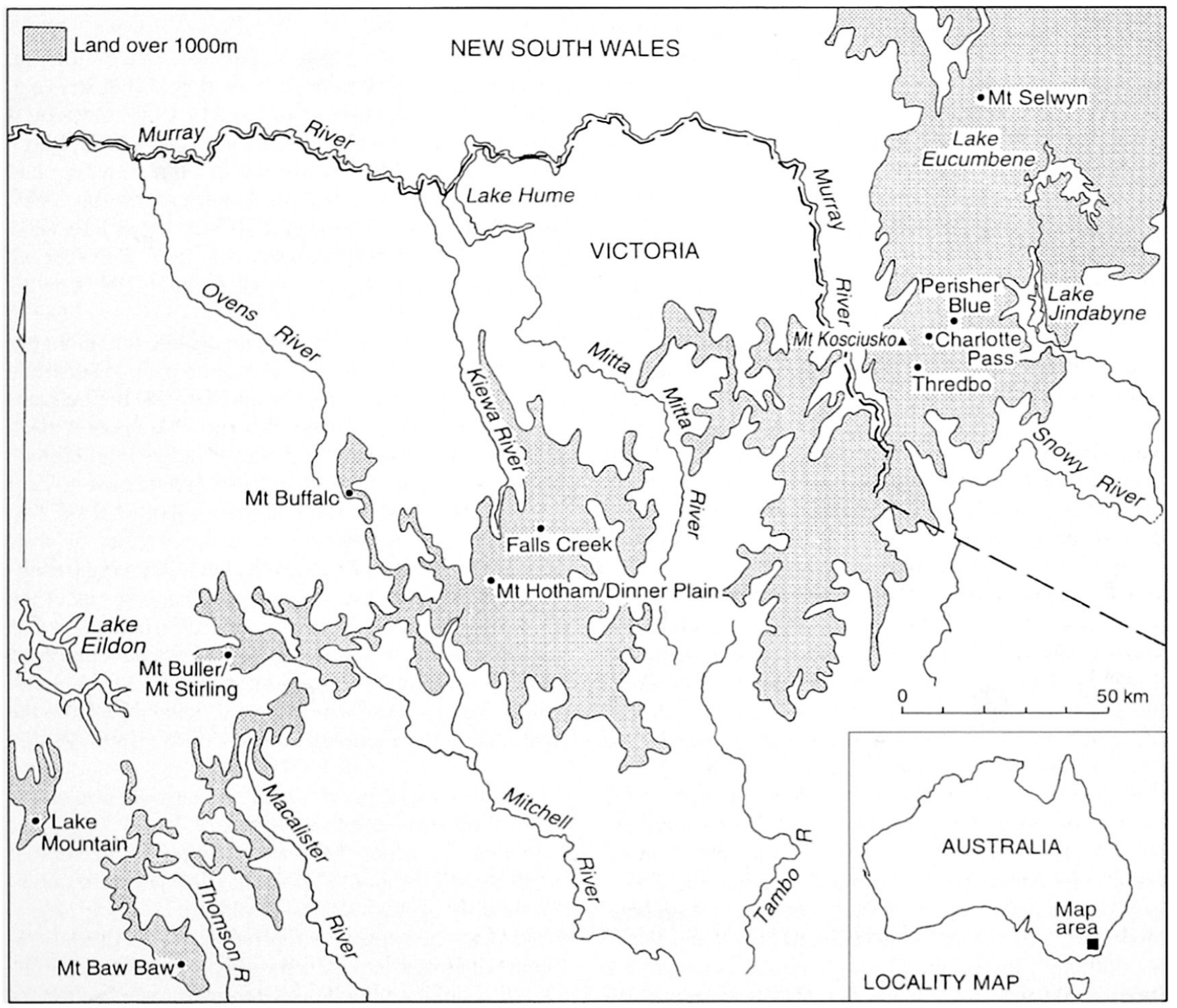

Fig. 1: The Australian ski resorts

Die Australischen Skigebiete

Les stations de ski australiennes 
The Australian winter tourism industry has to cope with highly-variable natural snowfalls (RUDDELL et al. 1990). The high variability of the snow-pack in Australia's alpine area is closely associated with (1) precipitation which is also, highly variable, and (2) the low altitude of the Australian Alps (the highest peak of the Australian continent, Mt Kosciusko, only reaches $2228 \mathrm{~m}$, whereas several ski fields in the European Alps for example reach up to $3500 \mathrm{~m}$ ). In addition, the relatively low latitude of the Australian Alps leads to high solar radiation and therefore a relatively high temperature regime, contributing to a variable snow-pack (HEwitT 1997). Snow-deficient winters (as in 1982, 1988, 1993 and 1998) during which only a small number of lifts operated for a shortened season, impose considerable difficulties for the whole alpine tourism industry. During these seasons resort operators do not make any profit on their large investments. Between 1985 and 1992, for example, over A $\$ 552$ million were invested in the resorts of the southern Snowy Mountains (GRENIER 1992), with the total capital investment in the Australian alpine resorts therefore likely to have exceeded several billion dollars. In addition, all associated commercial activities such as accommodation, restaurants, ski schools, ski shops and ski retailers are also affected by poor snow conditions. The considerable regional economic impact of the ski industry is therefore significantly reduced during poor snow seasons.

\section{Climate change and the snow-reliability of the Australian Alps}

\subsection{Method}

The method used to assess impacts of climate change on the snow reliability of Australian ski resorts has been developed by HAYLOCK et al., 1994 and WhETTON et al., 1996 and is described in more detail in these studies. It is a combination of: (1) the snow-cover duration model of Galloway (1988); (2) an observed interannual climate data set for the Australian Alps which was interpolated to a grid of high spatial resolution (using an interpolation method which allows for effect of elevation on climate); and (3) a best and worst case regional climate change scenario based on global climate models. The observed climate data of the grid are used as inputs to the «snow model which then produces output of snow-cover duration for each grid point. The regional climate change scenarios modify the input climate data to the model, in order to show the impact on simulated snow-cover duration of climate changes» (WHETTON et al. 1996).

Snow-cover duration for the grid points closest to the lowest and highest lifted points of the ski fields (altitude and distance) was calculated from the snow model. This calculation was carried out for current climate conditions, for the best case regional climate scenario and the worst case regional climate scenario as shown in Table 1. The computing of the snow data was undertaken in collaboration with the Australian National Science Organisation, the Commonwealth Scientific Industrial Research Organisation, CSIRO (Division of Atmospheric Research). The regional climate scenarios which were used as input to the GaLlowaY snow-cover duration model are based on the most recent IPCC climate scenarios (Houghton et al. 1996) and were calculated by Climate Impact Group (1996). They differ from those used by Haylock et al., 1994 and Whetron et al., 1996.

The advantage of GaLlowaY's snow model is its simplicity. The only climate input-data required in order to calculate snow accumulation and snow ablation are monthly mean temperature, monthly mean precipitation and standard deviation of daily temperature. Three factors, however, may have a negative effect on the value of the snow model for statements about the snow-reliability of ski fields:

- First, the snow-model provides no information on snow-depth. For example, days with snow-cover of 1 or $2 \mathrm{~cm}$ appear as snow-cover days. Skiing, however, is certainly not possible on snow of such depth.

- Second, there were several seasons in Australia with late snowfalls, when resorts closed operation in early October with a deep snow-pack still present (e.g. 1990, 1992). The snow-model calculates snow-cover duration throughout the entire year, without considering if a particular snow-cover day falls within or outside the «official» ski season. However, when calculating snow-cover duration under a changing climate regime the snow season will not only be shortened but will also «concentrate» on the coldest months of the year (July and August). Fewer days with snowcover outside the ski season are expected to be calculated by the model.

- Third, the snow model does not consider artificial snow-making.

The first two factors may result in an overestimation of the potential number of ski operation days. The third factor, the non-consideration of snow-making, results in an underestimation of the potential number of ski operation days by the snow model.

\subsection{Concept of Snow-Reliability and Results}

Different criteria have been discussed in the literature for assessing the snow-reliability of ski fields (e.g. see RisCh \& Bonorand 1972, Bezzola 1975, WanNeR \& SPECK 1975, KRIPPENDORF \& ANNASOHN 1976, ElSASSER et al. 1977, WitMER 1984). The so-called 100 days-rule, first suggested by WITMER (1986), summarised most of the previous research and stated that to profitably operate a ski field in Europe or North America, snow-cover sufficient for skiing (i.e., $30 \mathrm{~cm}$ for downhill skiing and $15 \mathrm{~cm}$ for cross country skiing) 
should last at least 100 days per season (between the first of December and the end of April for the Northern Hemisphere).

HewitT (1997) applied the 100-days rule to the three Australian resort Falls Creek, Mt Buller, and Mt Hotham for the 10 years 1986 to 1995 . He showed that Falls Creek matched the 100 days-rule during this period in only four seasons. The comparable figures for Mt Buller and Mt Hotham were two and four respectively. Although the Australian ski resorts therefore clearly do not match the European and North American standard of snow-reliability, the ski industry in Australia is financially viable. Therefore, it is clear that the 100-days rule is too strict in order to assess snow-reliability of Australian ski fields. The main reason for this is that Australian skiers tend to accept more marginal snow conditions than is commonly the case in North America or Europe (Galloway 1988). Slayter et al. (1985: 33 1) for example stated that:
«Australian skiers have the reputation of being prepared to ski on anything, particularly at the beginning and the end of the season.» This can be explained by the high percentage of novice, beginner and intermediate skiers skiing in Australian resorts (BUCKBY et al. 1993, Travers Morgan 1990). These skiers demand less sophisticated ski run variety than advanced and expert skiers. Also, in contrast to most people skiing in North America and Europe, skiing is still an exclusive activity for most Australians. Australian skiers therefore tend to have relatively low expectations toward snow conditions.

Following this, Galloway (1988) suggested that a mean snow season of 60 to 70 days is about the minimum for a financially viable downhill ski operation in Australia. From HewrrT's (1997) data it can be seen that in every winter between 1986 and 1995, Falls Creek had more than 60 days with more than $30 \mathrm{~cm}$ of snow. Mt Buller and Mt Hotham matched this criteria in eight out of the ten winters between 1986 and 1995.

\begin{tabular}{|l|c|c|c|c|}
\hline & $\begin{array}{c}\text { Best-case 2030 } \\
+0.3^{\circ} \mathrm{C} / 0 \%\end{array}$ & $\begin{array}{c}\text { Best-case 2070 } \\
+0.6^{\circ} \mathrm{C} / 0 \%\end{array}$ & $\begin{array}{c}\text { Worst-case 2030 } \\
+1.3^{\circ} \mathrm{C} /-8 \%\end{array}$ & $\begin{array}{c}\text { Worst-case 2070 } \\
+3.4^{\circ} \mathrm{C} /-20 \%\end{array}$ \\
\hline Charlotte Pass & + & + & + & - \\
\hline Thredbo & + & + & $? /+$ & - \\
\hline Persisher-Blue & + & + & $? /+$ & - \\
\hline Falls Creek & + & + & $? /+$ & - \\
\hline Hotham & + & $+/+$ & - & - \\
\hline Mt Buller & + & $? /+$ & - & - \\
\hline Mt Buffalo & + & $?$ & - & - \\
\hline Selwyn & + & - & & - \\
\hline Mt Baw Baw & - & & + & - \\
\hline
\end{tabular}

Tab. 1: Prerequisites of ski fields in terms of natural snow-cover duration for a finanacialy viable ski industry

- The first figure of the climate scenario indicates changes in temperature $\left({ }^{\circ} \mathrm{C}\right)$, the second figure shows changes in precipitation $(\%)$

- $(+)$ indicates that the pre-requisites in terms of natural snow-cover duration for a financially viable ski operation (60-days rule) are met; (?) indicates that the pre-requisite in ternis of natural snow-cover duration for a financially viable ski operation are questionable; (-) indicates that the pre-requisite in terms of natural snow-cover duration for a financially viable ski operation are not met

Schneesicherheit der Skigebiete

- Änderungen der Temperatur in ${ }^{\circ} \mathrm{C} /$ Prozentuale Änderung der Niederschlagsmenge

- (+) Die Voraussetzungen für einen profitablen Skibetrieb sind gegeben; (?) Die Voraussetzungen für einen profitablen Skibetrieb sind fragwürdig; (-) Die Voraussetzungen für einen profitablen Skibetrieb sind nicht gegeben

Garantie d'enneigement des stations skiables

- Changements de la température en ${ }^{\circ} \mathrm{C} /$ Changement en pourcentage des précipitations

- (+) Les conditions pour l'exploitation du ski sont assurées; (?) Les conditions pour une exploitation du ski profitable sont incertaines; (-) Les conditions pour une exploitation du ski profitable ne sont pas assurées 
The minimum of approximately 60 days of operation per season for a ski field to break even, has been confirmed by most interviewed resort managers. The snow reliability of Australian ski fields is therefore defined as follows:

An Australian ski field is considered snow-reliable if skiing is possible on at least 60 days during the ski season (i.e., between the June long weekend and the October long weekend).

The aim therefore was to show if Australian ski resorts would still match the 60 -days rule under changing climate conditions. Table 1 shows the results of the snowcover duration calculation under different climate scenarios.

Assuming the best case scenario, all but one resort (Mt Baw Baw) match the 60-days rule in 2030. In 2070 (with the best-case scenario) five resorts still have the pre-requisites for a financially viable ski industry (Perisher-Blue, Charlotte Pass, Thredbo, Falls Creek, Hotham), while the prerequisites are questionable at Mount Buller, Mount Buffalo and Selwyn Snow fields. At Mt Baw Baw a successful ski operation would not be possible. Assuming the worst case scenario for 2030, a financially viable ski operation would not be possible at Selwyn Snow fields, Mount Buffalo and Mt Baw Baw. Charlotte Pass would be the only resort still achieving the 60 days rule. At all other resorts, ski operation would concentrate on the highest areas of today's ski fields, while top to bottom skiing would not be possible in most resorts. With the worst case scenario, none of today's ski resorts would be operating a profitable ski industry in 2070.

When comparing New South Wales and Victorian resorts (see Figure 1), it is evident that the latter are more vulnerable to climate change than the New South Wales resorts. If climate changes as outlined occurred, a concentration of the ski industry to the highest ski fields (Hotham and Falls Creek in Victoria and Charlotte Pass, Perisher-Blue and Thredbo in New South Wales) is expected. Assuming today's snow-making technology, the lower resorts would have to close down. In the higher ski fields, where skiing will concentrate, environmental problems (waste water, rubbish) and the pressure for extension into higher alpine areas are likely to increase. This would undoubtedly result in conflicts with both conservation groups and the Alpine National Parks.

It is worth mentioning that the snow-model used here produces average snow data. Snow records in the Australian Alps show, that in the past, two out of ten years were poor snow seasons. Climate change is expected to increase the frequency of poor snow years, while the number of good snow years will decrease. The ski industry is undoubtedly more vulnerable to a series of extreme events than to a relatively small change of average conditions. A consecutive series of poor snow seasons, for example, certainly has a greater impact on the ski industry than a relatively slow decrease in the number of days with snow-cover. This was clearly illustrated during the three consecutive snow-deficient winters in the European Alps (1987-1989) which had severe impacts on the whole alpine tourism industry (see ABEGG 1996, for example).

An important question for ski resort operators when facing climate change is therefore the maximum number of years with poor snow conditions over a certain period of time (e.g., 10 years) that the resorts can accommodate in their financial plans.

It is evident that sufficient snow conditions are of great importance for the ski industry. However, it has to be emphasised that good snow conditions are a necessity but not the only condition needed for a financially-viable ski industry. Other factors, such as leisure trends, the general development of the national economy or the marketing of the resorts also influence the ski tourism market. Also, not only the snow conditions but also the attitudes of skiers and response strategies of resorts are expected to change if climate change were to occur. The following section discusses the perception of representatives of the Australian ski industry concerning the possibility of changing climate due to the enhanced greenhouse effect and discusses possible response strategies of the industry to climate change

\section{Perception and Possible Response of the Ski Industry}

\subsection{Perception}

The implications of future climate change due to enhanced greenhouse effect in general, possible impacts on the tourism industry, and the significance of these impacts were discussed with resort managers of all Australian alpine resorts and key employees of the management bodies of the ski industry (Alpine Resorts Commission and New South Wales National Parkes and Wildlife Service) $(n=17)$. As a result of these interviews it became clear that:

- Climate change due to enhanced greenhouse effect is of no consideration in current operating and planning the ski fields; and

- the ski industry perceives research dealing with impacts of climate change on the alpine region and the ensuing media coverage as a threat.

The majority of resort managers (9 of 10) considered the possibility of future climate change due to enhanced greenhouse effect as not important in operating and planning the resort. The three main reasons given for this were:

- The resorts are concerned about short-term profits. The time-frame of climate scenarios are too long to be of importance for the resorts. They need to know 
what will happen in the next 3 to 5 years. Projections of up to 30 or even 100 years are not considered as being useful;

- the science of future climate change is not good enough. It is not yet proven that global temperature will increase; and

- even if there will be less snow due to climate change, it is argued that technology may improve so, that resorts will be able to produce snow at much higher temperatures than today.

It is interesting to note that Swiss tourism managers are much more concerned about climate change (ABEGG 1996) than their Australian colleagues. The only resort where the possibility of future climate change has been an issue is Thredbo. At the end of the 1980s, when public awareness about future climate change peaked, Thredbo employed a research officer with the task of investigating possible impacts of climate change and making recommendations to, the management board (KeFFORD 1988). It is not clear if the report had direct consequences for the planning of the ski field in Thredbo. It can, however, be expected that the extensive expansion of snow-making and the strong promotion of all year round tourism by Thredbo are at least partly an outcome of this report.

In summary, the general opinion among resort managers was that resorts already do everything possible in order to adapt to the current high variability of snowfall (e.g., snow-making, snow-farming). They believe that these same strategies would help if there were to be less snow in the future (although it was not believed that this would happen). With the exception of Thredbo, none of the resorts explicitly considered the possibility of a diminishing snow-pack due to climate change in the planning and operation of resorts. It may, however, be argued that the relatively effective adaptation of the Australian ski industry in terms of technical adaptation strategies to the current large snow-variability (see next Section) is the best way to adapt to an uncertain future climate, and that the industry therefore implicitly already adapts to climate change (for a general discussion about adaptation to current climate variability versus adaptation to future climate change, see SMIT 1993; BURTON 1997).

Interviewees of the ski industry perceived research on impacts of climate change due to the enhanced greenhouse effect on the alpine area and the attendant media coverage as a threat for their business. It was pointed out that newspaper headlines such as «Our ski slopes melt away» (HERALD Sun 22 February 1994), «Ski slopes face dry run» (Herald Sun 11 June 1997) or «Climate chaos for ski resorts» (The Mercury 11 June 1997) are bad publicity for the alpine tourism industry. It was generally felt that this media coverage has the potential to influence investment in the alpine area (e.g. real estate) in a negative way and may also stop tourists

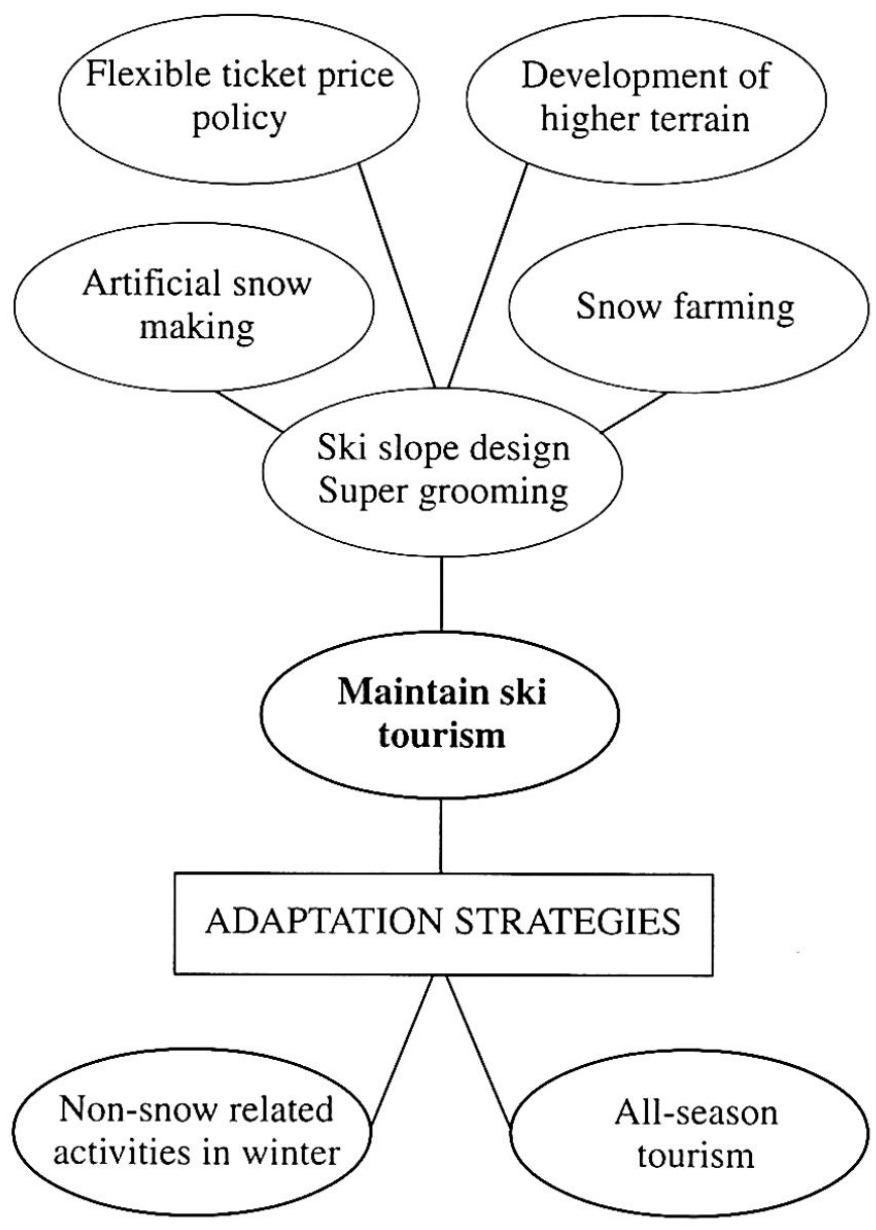

Fig. 2: Response strategies

Anpassungsstrategien

Stratégies de réponse

from going skiing. Also, the press attache to the Australian Professional Ski Shop Association in 1991 wrote: «,... the positive effect of last winter [1991] has removed the Greenhouse effect from the front pages of the newspapers, thus allowing normal or increased trading» (TAlbot 1991: 8). This perception of the ski industry about climate change media coverage being a main threat for the ski industry, often results in an agressive attitude towards anybody who is «talking greenhouse». There is no doubt that media coverage projecting «the end»of the commercial ski operation in the Australian Alps due to, climate change is amunition for conservation groups which oppose any further development of the existing ski fields. The Victorian National Parks Association for example, argued that global warming and greenhouse implications do not bode well for the long term viability of downhill ski resorts in Australia and concluded that therefore no further development of the ski resorts (as discussed for Mt Stirling) should be undertaken (WATERMAN 1996). The issue of impacts of climate change on the alpine area is therefore very polit- 
ical. Both sides (the ski industry and conservation groups) use existing data very selectively for their own purpose.

In summary, climate change due to enhanced greenhouse effect is on the whole of no consideration in current planning and operation of Australian ski resorts. The ski industry fears possible negative economic impacts of media reports stemming from the "global warming» discussion. Most representatives of the industry therefore deny that future climate change would have severe impacts on the alpine region.

\subsection{Possible Response Strategies of the Ski Industry}

Figure 2 shows the range of possible response strategies of the resorts to climate change. They can be subdivided into (1) those which maintain ski tourism (including artificial snow-making, flexible ticket price policy, ski slope design/super grooming, development of higher terrain, snow farming), (2) non-snow related activities in winter, and (3) all-season visitation. Each adaptation strategies is briefly described below.

Because of its importance, "artificial snow-making» and «all-season tourism» are discussed in further detail.

- A flexible ticket price policy adapts ticket prices in accordance to the number of lifts running in order to attract more skiers in poor snow seasons.

- Ski slope design and super grooming both aim at maintaining a long lasting snow cover. Ski slope design includes consideration of micro climate effects associated with aspect (wind, direction, sun), subsurface drainage, as well as the space requirement for skiers. Super grooming involves the removal of surface irregulation such as rocks and bushes to provide an even surface.

- Higher areas generally offer greater snow-depth and drier snow and are therefore an attractive option for development of ski fields

- Snow farming includes snow fencing, transportation of snow from surplus accumulation areas to highwear areas and snow grooming.

- The supply of non-snow related activities in winter aims at reducing the snow-reliance of the alpine tourism industry. The idea is to offer skiers alternative activities if skiing is not possible.

Most of these strategies are «no regrets» strategies, that is they are worthy of consideration even if climate change does not occur because of today's high variability of snowfalls. It should be mentioned that those adaptation strategies summarised under «maintain ski tourism» (Figure 2) are relatively well developed in Australia. Not enough has been done in the development and implementation of «non-snow related activities in winter» and an enhanced «all-season visitation».

\section{Snow-Making}

The results of a skier survey undertaken in the Perisher Range resorts during the 1996 ski season (KoENIG 1998) showed that «lots of snow-making» is the most important thing skiers are looking for when choosing a resort in future snow-deficient winters $(89 \%$ of respondents considered it as important). Extensive expansion of snow-making therefore remains the most promising strategy in order to attract skiers in poor snow seasons. However, it is important to stress that snowmaking facilities such as fixed high pressure snow guns, water pipelines and water dams may affect the appearance of the resorts in summer and are thus expected to impact the growth of all-season visitation in a negative way. Also, economic, climatic, and ecological factors may limit the future extensive expansion of snow-making facilities:

Favourable climate conditions for snow-making are low temperatures and low humidity. Temperatures below $-5^{\circ} \mathrm{C}$ and humidity of less than $65 \%$ are ideal (RUFFINI 1993). Snow-making additives (e.g., Snowmax) which are widely used in the Australian Alps (NEw South Wales National Park and Wildlife Service 1994, DARBY 1994) and advances in snow-making technology, however, allow the production of snow under more marginal conditions. More research into impacts of climate change on the potential hours of snow-making is required. Suggestions referring to impacts of climate change on the potential hours of snow-making have been made by WHETTON (1996). To be most beneficial, this research should be undertaken in collaboration with the ski-industry.

Artificial snow-making requires enormous amounts of water. Water shortage and other environmental issues may restrain the extension of snow-making and/or increase investment costs. Artificial snow-making is expensive. High costs, together with water shortage, are the main reasons for resorts not extending their area of snow-making.

There is no doubt that snow-making improved the skiing conditions and therefore stabilised the revenue of the Australian ski industry over the last 10 years. However, it is unlikely that artificial snow-making can, for the reasons discussed above, replace natural snow in the future. To open an entire resort, the ski industry will still largely contingent on the presence of sufficient natural snow. Nevertheless, even under climate change, there will be times when snow making will be possible. A large snow-making capacity is therefore expected to remain an important market advantage if climate change were to occur. The shorter the time period gets when snow-making is possible, the more important will a high snow-making capacity become. This will be a clear disadvantage for smaller resorts with less financial means and will enhance the concentration of the ski industry on the larger, financially stronger resorts. 


\section{All-season tourism}

The most effective strategy to reduce snow-reliance of the alpine tourism industry is the enhancement of allseason tourism. This includes tourism in spring, summer and autumn and all climate independent tourism such as conference tourism, educational tourism and health tourism. Although all-year patronage in the Australian alpine resorts has increased over the last few years, it is, with the exception of Mt Buffalo and Thredbo, still marginal. However, the successful examples of the two resorts Thredbo and Mt Buffalo, the general observed trend away from beach holidays towards activity and education holidays, and the growth of adventure sports such as mountain biking and para-gliding (e.g. LYNCH \& VEAL 1996) all indicate a promising future for all-year tourism in the Australian Alps.

Clearly, those resorts with an attractive appearance, offering a lively village centre with facilities and services such as shops, restaurants, coffee shops, news agencies etc., have good pre-requisites to increase all-year patronage. It is not surprising that Thredbo with its «village atmosphere» has the highest percentage of overnight stays and day-trippers in summer of all New South Wales resorts. It can therefore be stated that an attractive appearance of the resort and the availability of facilities and services are the most important prerequisites for increasing all-year tourism.

While the mountain scenery and the mainly undisturbed alpine environment is certainly the basis for an increased all-year visitation, it is not alone sufficient for increasing non-winter visitation. Resorts need to attract potential all-year visitors with «something special». All alpine resorts can offer access to an undisturbed alpine environment and most resorts offer activities such as mountain biking, guided walks, horse riding etc. It is important to stress that with an expected increase in competitiveness between the resorts for all-year tourism, it will be necessary to have one or several Unique Selling Positions (USP) in order to survive. This USP can be a natural or built site, or a specific activity exclusively offered in the resort. Thredbo, for example, offers the closest walking distance to the highest peak of Australia (Mt Kosciusko) and is the only resort with the so called "Alpine Slide». Mt Buffalo is one of the few places in Australia where hang-gliders train and competitions are organised regularly (e.g. women's world championships in 1996). Another USP of Mt Buffalo is the 1910 built Chalet Hotel, a unique building in the Alps. It is one of Australia oldest and largest historic guesthouses. Also, both resorts offer cultural events which are unique in the Alps. Thredbo holds annual Blues, Jazz, and Film festivals and Mt Buffalo organises an annual «Opera Chorus in the Alps». All events report remarkable success.

\section{Conclusions}

Climate change due to an enhanced greenhouse effect is expected to concentrate the Australian ski industry on the highest resorts with the best natural snow falls and the best conditions for snow-making. This would create «two classes» of resorts (1) smaller resorts at lower altitudes which will lose their downhill ski operation first; and (2) larger resorts, at higher altitudes where downhill skiing remains possible. However, in the long run (assuming worst case climate scenario for 2070) none of Australia's resorts will be snow-reliable.

Mt Buller, Mt Buffalo, Selwyn Snow fields and Mt Baw Baw will lose their downhill ski industry first. Clearly, assuming today's snow-making technology, only those resorts which diversify into all-year tourism will be able to maintain a financially viable tourism industry. Depending on their degree of diversification, resorts may be able to remain in the tourism business or will, in conjunction with the disappearance of the snow, lose their tourism industry altogether. All-year tourism must become the main source of income for these resorts. In winters with good snowfalls these marginal ski resorts may still offer groomed cross country skiing tracks, which are much cheaper to maintain than downhill ski facilities (i.e. lifts, groomed downhill slopes). Resorts which make enough profit in the non-snow season may also be able to afford the luxury of maintaining one or two ski lifts which operate in good snow seasons. In other words, marginal resorts which maintain downhill ski operation under climate change (e.g. for image reasons) will have to subsidise this with a profitable summer tourism industry. Due to the overall decline of downhill ski operation under climate change (less visitors, less snow-making, less super grooming), negative impacts on the alpine environment will decrease in these marginal resorts.

Australia's ski operations are expected to concentrate at Charlotte Pass, Thredbo, Perisher-Blue, Falls Creek and Hotham if climate change were to occur. It is important to stress that these ski fields will also have to cope with more marginal snow seasons under changing climate conditions. The decrease in skier visitation due to more poor snow seasons will result in lower incomes for resorts. Simultaneously, costs will increase due to the requirement of more snow-making facilities, extended areas of super grooming and more sophisticated snow farming because of less natural snowfalls. These two factors, decreasing income and increasing costs, are expected to decrease the profit of the ski resorts significantly. Hence, although skiing remains possible at these resorts, those which reduce their snow-reliance through the provision of non-snow related activities in winter and diversification into all-year tourism will be most profitable. The expected extension of super grooming, 
in combination with more snow-making is expected to increase the pressure on the alpine environment in these resort areas.

Australian ski resorts need to diversify or ultimately close due to climate change. It is worth stressing again that diversification into all-year tourism is not only essential in order to survive under climate change, but would already be under current climate conditions, of great benefit due to the high interannual variability of snowfalls.

\section{Acknowledgements}

The author thanks Prof. Dr. H. Elsasser, Dr. B. ABEgG and R. BÜRKI for providing a flexible and fun working environment and Dr. F. ElLIS for all the support during this study.

\section{Literature Cited}

ABEGG, B. (1996): Klimaänderung und Tourismus. Klimafolgenforschung am Beispiel des Wintertourismus in den Schweizer Alpen. - = Schlussbericht NFP 31, Zürich: 1-222.

Bezzola, A. (1975): Probleme der Eignung und Aufnahmekapazität touristischer Bergregionen der Schweiz. - In: KASPAR, C. (ed.) (1975): St. Galler Beiträge zum Fremdenverkehr und zur Verkehrswirtschaft. - = Reihe Fremdenverkehr 7, Berne/Stuttgart.

Boylen, L. (1997): Beauty of the Highest Order. - In: Australian Geographic (Special Edition Explore Australia) 4: 56-79.

Buckby M., Burgan B., Molloy J. \& S. Mc Donald (1993): The Economic Significance of Alpine Resorts. - Adelaide: The Centre for South Australian Economic Studies.

BURTON, I. (1997): Vulnerability and Adaptative Response in the Context of Climate and Climate Change. In: Climatic Change 36: 185-196.

Climate Impact Group (1996): Climate Change Scenarios for the Australian Region. - Melbourne: Climate Impact Group.

CoHen, E. (1978): The impact of tourism on the physical environment. - In: Annals of tourism research 3: 215-237.

DARBY J. (1994): Skiing in Victoria. - Melbourne: McArthur.

Elsasser B., Fehr U. \& F. Mauerhofer (1977): Erholungsräume im Berggebiet. - Zürich: Geographisches Institut der Universität Zürich.

Galloway, R.W. (1988): The potential impact of climate changes on the Australian ski fields. - In: PEANNAN, G. (ed.): Greenhouse - Planning for Climate Change. - Melbourne, Moore: 428-437.

Grenier, P. (1992): Skiing in the Australian Alps: development and conflict. The Australian Alps. - In: Revue de Géographie Alpine 2-3: 227-275.
Haylock, M. et al. (1994): Haylock, M., Whetton, P.H. \& C. Desborough: Climate Change and Snow Cover Duration in the Victorian Alps. - = Report prepared for the Environmental Protection Authority, Publication Nr. 403, Melbourne.

Herald Sun 22 February 1994: Our ski slopes melt away. - Sydney: 16.

Herald Sun 11 June 1997: Ski slopes face dry run. Sydney: 25 .

HewITT, S. (1997): An impact analysis of an enhanced greenhouse climate change on the Australian alpine snow pack. $-=\mathrm{PhD}$ thesis, University of Melbourne, Melbourne.

Houghton, J.T. et al. (1996): Houghton J.T., Meira Filho, L.G., Callander, B.A., Harris, N., KattenBERG, A. \& K. MASKell: Climate Change 1995. The Science of Climate Change. - Cambridge Universidy Press: Cambridge.

KefFord, M. (1988): Thredbo Weather and the Greenhouse Effect. - = Report prepared for Kosciusko Thredbo Pty. Ltd. Sydney.

Keys, J.R. et al. (1990): Keys, J.R., Parrott, P.N. \& M.P. Mosley: Recreation and Tourism. - In: MiNISTRY For the ENvironment (ed.): Climate Change - Impacts on New Zealand. - Wellington, Government Publishing: 174-178.

KoEnIG, U. (1998): Climate change and the Australian ski industry: investigation into the decision-making process of skiers and possible adaptation strategies of the tourism industry. - In: Green, K. (ed.): Snow: A Natural History; an uncertain Future. - Australian Alps Liaison Committee, Canberra: 207-223.

KPMG Management Consulting (1994): New South Wales Alpine Industry: Economic Impact Study. - = Report prepared for the Australian Ski Areas Associaton, Adelaide.

KRIPPENDORF, J. \& K. ANNASOHN (1976): Grundlagen zu den Leitlinien für die Berggebietsförderung. - Bern. Krupp, C. (1995): Klimaänderung und die Folgen. Eine exemplarische Fallstudie über die Möglichkeiten und Grenzen einer interdisziplinären Klimafolgenforschung. - Berlin: Bozen.

Lamothe \& Périard Consultants (1987): Prospective du changement climatique pour les resources naturelles du Québec phase 1: L'industrie du ski alpin. Rapport final (unpuplished).

LyNCH, R. \& A.J. VEal (1996): Australian Leisure. Melbourne: Longman press.

New South Wales National Parks and Wildlife SERvice (1994): Plan of Management Amendements 1994. - Sydney: New South Wales National Parks and Wildlife Service.

Österreichische AKademie der Wissenschaften (several authors) (1993): Anthropogene Klimaänderungen: Mögliche Auswirkungen auf Österreich - mögliche Massnahmen in Österreich. - Wien.

PIgram, J.J. (1980): Environmental implications of 
tourism development. - In: Annals of tourism research 4: 554-583.

PRICE, M.F. (1994): Climate and Tourism in the Mountains: An Introduction. - Paper presented at the conférence «Neige et Climat», 22-23 September 1994, Geneva.

Risch, P. \& M. BonORand (1972): FremdenverkehrsEignungskataser und Entwicklungsprogramm für potentielle neue Fremdenverkerkehrsgebiete des Kantons Graubünden. - Bern.

Ruddell, A.R., Budd, W.F., Smith, I.N., Keage, P.L. \& R. JonEs (1990): The South East Australian Alpine Climate Study. - = Report prepared for the Alpine Resort Commission, Melbourne.

Ruffini, F. (1993): Geregelter Einsatz von Beschneiungsanlagen. - In: Mitteilungen zum Natur- und Umweltschutz in Südtirol, Naturschutzblatt 4: 3-9.

Slatyer, R.O., Cochrane, P.M. \& R.W. Galloway (1985): Duration and Extent of Snow Cover in the Snowy Mountains and a comparison with Switzerland. - In: Search 11-12: 327-331.

Smit, B. (1993): Adaptation to Climate Variability and Change: Report on the Task Force on Climate Adaptation. - University of Guelph: Department of Geography. Smith, K. (1990): Tourism and Climate Change. - In: Land Use Policy 2: 176-180.

TALBot, I. (1991): Professional Ski Shop Association. - Paper presented at the 1991 Ski Areas Trade Show and Conference, 12-14 June 1991, Thredbo.

The Mercury 11 June 1997: Climate chaos for ski resorts. - Brisbane: 11.

Timmermann, P. (1989): Everything Else Will Not Remain Equal: The Challenge of Social Research in the Face of a Global Climate Warming. Impacts of Climate Change on the Great Lakes Basin. - = Report of the first U.S.-Canada Symposium on Impacts of Climate Change on the Great Lakes Basin, 27-29 September 1988, Oak Brook - Illinois: 61-76.

Travers Morgan (1990): Skier Market Survey. Working papers 1-7. $-=$ Report prepared for the New South Wales National Parks and Wildlife Service, Jindabyne. United Kingdom Climate Change Impact Review Group (1996): Recreation and Tourism. - In: DEPARTMENT OF THE ENVIRONMENT (ed.): Review of the Potential Effects of Climate Change in the United Kingdom. - London, Price: 199-210.

WALL, G. (1992): Tourism Alternatives in an Era of Global Climatic Change. - In: SMITH, V. \& W. EADINGTON (eds.): Potential and Problems in the Development of Tourism. - Philadelphia, Wood and Son: 194-215.

WALL, G. (1993): Impacts of Climate Change on Recreation and Tourism in North America. - = Report prepared for the Office of Technology Assessment, Congress of the United States, Washington.

WALl, G. et al. (1985): WAll, G., Harrison, R., KiNNaIRD, V., Mc Boyle, G. \& C. Quinlan: Climate Change and its Impacts on Ontario: Tourism and Recre- ation. $-=$ Report prepared for Environment Canada, Ontario Region, Toronto.

Wanner, H. \& H. SPeCK (1975): Zum Problem der Schneesicherheit im Bergland zwischen Sense und Gürbe. - In: Informationen und Beiträge der Klimaforschung 14: 16-35.

WATERRNAN R. (1996): The uphill battle for Mt Stirling - time to act. - In: Park Watch, 185: 16-21.

WhetTon, P.H. (1996): Assessing the impact of climate change on total (fiatural and artificial) snow cover in the Victorian Alps: Some suggested approaches. - CSIRO: Melbourne (unpublished).

Whetton, P.H. et al. (1996): Whetton, P.H., HaYLock, M.R. \& R.W. Galloway: Climate Change and Snow-Cover Duration in the Australian Alps. - In: Climatic Change 32: 447-479.

WITMER, U. (1984): Eine Methode zur flächendeckenden Kartierung von Schneehöhen unter Berücksichtigung von reliefbedingten Einflüssen. $-=$ Geographica Bernensia G 21, Bern: 1-140.

WitMER, U. (1986): Erfassung, Bearbeitung und Kartierung von Schneedaten in der Schweiz. $-=$ Geographica Bernensia,G 25, Bern: 1-215.

\section{Summary: \\ Climate Change and Snow Tourism in Australia}

This paper examines impacts of climate change as outlined by the Intergovernmental Panel of Climate Change (IPCQ on the snow-reliability of the Australian ski fields. It is shown that with a «best case» climate scenario for the Australian Alps, all but one resort (Mt Baw Baw) would have at least 60 days of natural snowcover in 2030 and would therefore still be snow-reliable. With a «worst case» scenario in 2070 on the other hand, none of Australia's current ski resorts would be able to operate a profitable ski industry. Possible adaptation strategies of the ski industry to climate change are suggested. It is demonstrated that the more technical adaptation strategies such as snow-making, super-grooming, and snow-farming are well-developed in Australia, while clearly not enough has been done in both the development of non-snow related activities in winter and an enhanced all-season visitation. This paper therefore argues that Australian ski resorts need to diversify more than they do today or they will ultimately close due to the negative effects of climate change.

\section{Zusammenfassung:}

\section{Klimaänderung und Scheetourismus in Australien}

Der vorliegende Artikel untersucht mittels des «Galloway Schneemodell» Auswirkungen einer möglichen Klimaänderung auf die Schneesicherheit aller australischen Skigebiete für die Jahre 2030 und 2070. Mit einem «best case scenario» für das Jahr 2030 verfügen mit einer Ausnahme (Mt Baw Baw) alle Skigebiete über mindestens 60 Schneedeckentage und können daher als 
schneesicher eingestuft werden. Mit einem «worst case scenario» für das Jahr 2070 allerdings würde keines der australischen Skigebiete die naturräumlichen Voraussetzungen für einen profitablen Skitourismus erfüllen. In einem zweiten Teil werden mögliche Anpassungsstrategien für die Tourismuswirtschaft bei einer möglichen Klimaänderung vorgeschlagen und diskutiert. Es wird gezeigt, dass vor allem technische Strategien (u.a. Kunstschnee, Planien) in den letzten 15 Jahren stark vorangetrieben wurden. Nicht genug wurde im Bereich der Diversifikation des touristischen Angebotes unternommen (Alternativen zu den schneeabhängigen Angeboten, Vier-Jahreszeiten-Tourismus). Eine Diversifikation des touristischen Angebotes ist jedoch Voraussetzung für die alpinen Tourismusorte, um unter einer Klimaänderung wirtschaftlich zu überleben.

\section{Résumé : Changement climatique et tourisme hivernal en Autralia}

L'article présent examine à l'aide du «modèle de neige Galloway» les effets possibles qu'un changement climatique pourrait avoir sur les conditions d'enneigement de tous les domaines skiables australiens pour les années 2030 et 2070 . En fonction d'une situation optimale pour l'an 2030, tous les domaines skiables, à l'exception du Mt Baw Baw, bénéficieraient d'une période d'au moins 60 jours d'enneigement naturel permet- tant la pratique du ski: ils peuvent donc ainsi être jugés comme assurés. Dans le pire des cas pour l'an 2070 cependant, aucun des domaines skiables australiens ne remplirait les conditions pour un tourisme de ski économiquement profitable. Dans une deuxième partie seront discutées et proposées les stratégies d'adaptation possibles pour l'économie touristique en cas de changement climatique. Il est démontré que, dans les derniers quinze ans, on a surtout encouragé des stratégies techniques (entre autre: neige artificielle). On n'a, cependant, pas assez fait dans les domaines de la diversification de l'offre touristique (alternatives aux offres dépendantes de la neige, tourisme quatre saison). Une diversification de l'offre touristique est toutefois indispensable aux lieus touristiques alpins s'ils veulent, en cas de changement climatique, survivre économiquement.

Dr. Urs König, Australian Graduate School of Management, University of New South Wales, Botany Street, Gate 10, Randwick, NSW 2031, Australia.

e-mail: ursk@agsm.edu.au 